\title{
Migrant Workers in Russia. Global Challenges and the Shadow Economy in Societal Transformation
}

\author{
Anna-Lisa Heusala \& Kaarina Aitamurto (red.) \\ New York: Routledge 2017 \\ 161 sider. ISBN 9781138100831
}

\begin{abstract}
Omtalt av Natalia Moen-Larsen [stipendiat, Institutt for sosiologi og samfunnsgeografi, Universitetet i Oslo/forsker, Norsk utenrikspolitisk institutt (NUPI), natalia.moen-larsen@sosgeo.uio.no]
\end{abstract}

Det er en utfordring å forske på migrasjon i en russisk kontekst. Feltet er både fascinerende og uendelig komplisert. Store fortellinger om det tapte Imperiet kolliderer med etnisk nasjonalistiske fortellinger om behovet for å ivareta «Russland for russere». Løfter om fri flyt av arbeidskraft mellom medlemslandene i den Eurasiske økonomiske unionen kan stå i strid med vektleggingen av sikkerhet og kampen mot narkotikasmugling fra Sentral-Asia. Russlands behov for arbeidskraft er i konflikt med et komplisert lovverk som nærmest gjør det umulig for arbeidsmigranter å jobbe på lovlig vis. De fleste russere anser russiske statsborgere fra Nord-Kaukasus som mer fremmede enn innvandrere fra Hviterussland. På toppen av alt dette har Russland helt siden 2014 måttet håndtere en stor mengde flyktninger fra Ukraina som hverken samfunnet, lovverket eller statsbudsjettet var forberedt på.

Alle disse temaene blir, i større eller mindre grad, berørt i boken Migrant Workers in Russia. Global Challenges and the Shadow Economy in Societal Transformation som er redigert av Anna-Lisa Heusala og Kaarina Aitamurto fra Aleksanteri-instituttet ved Universitetet i Helsingfors. Bokens hovedfokus er på arbeidsmigrasjon. Som flere av bidragsyterne understreker er Russland på andre plass etter USA i forhold til antall arbeidsmigranter. De fleste av migrantene kommer fra tidligere medlemsland av Sovjetunionen, hovedsakelig fra land i Sentral-Asia. I Migrant Workers in Russia poengteres det at en stor del av arbeidsmigrantene jobber uten arbeidstillatelse boken går inn på flere grunner til at det er slik - og dermed bidrar til skyggeøkonomien i Russland.

I introduksjonen definerer Heusala et ganske vidt formål for boken. Målet er «to look at the wide array of consequences for societal transformation in Russia created by the use of a large-scale migrant workforce under shadow economic and globalised conditions» (s. 3). Redaktøren understreker at bokens bidrag til den massive 
litteraturen på feltet «migrasjon og samfunnsendring» (societal transformation) er å rette oppmerksomheten mot skyggeøkonomien.

Boken har syv analysekapitler som er skrevet av åtte bidragsytere, inkludert redaktørene. Rekkefølgen på kapitlene er tematisk strukturert - de første tre kapitlene sier noe om endringer i russisk politikk, og de resterende fire sier noe om endring i russisk lovverk og institusjoner. Temaene for analysene er blant annet migrasjonslovverk, utenrikspolitikk og Den eurasiske økonomiske unionen, sammenhengene mellom arbeidsmigrasjon, skyggeøkonomi og organisert kriminalitet, samt religion og integrering. Boken er dermed et kaleidoskop av ulike stemmer, metodiske tilnærminger og tematikker. Enhver leser med interesse for migrasjonsfeltet i Russland vil finne nyttig informasjon i Migrant Workers in Russia. Samtidig vil nok andre deler av boken fremstå som mindre relevante. Dette er helt legitimt for en antologi som denne. Nedenfor vil jeg trekke frem to av kapitlene som var av størst interesse for denne leseren.

I bokens fjerde kapittel ser Jussi Lassila på hvordan «migranter» og «flyktninger» brukes i politisk diskurs i Russland i 2013 og 2014. Rammen for studien er identitetspolitikken i Russland, hvor spørsmålet om nasjonal identitet står sentralt. For hvordan kan imperialistisk nasjonalisme kombineres med etnisk nasjonalisme? Hvordan kan man kombinere økende xenofobiske holdninger blant russere med behovet for å ivareta en sterk og fleretnisk stat? Lassila tar for seg både pro-myndighetsdiskurs i russiske aviser og diskursen til opposisjonspolitikeren Aleksej Navalnyj og viser hvordan arbeidere fra Sentral-Asia diskursivt kobles til kriminelle nettverk og korrupsjon. Sentralasiatere presenteres som radikalt annerledes enn russere og inkompatible med russisk tradisjon og kultur, i motsetning til flyktninger fra Ukraina som anses som bedre egnet for et russisk arbeidsmarked, på grunn av deres språk og kulturelle tilhørighet. Lassila argumenterer videre for at strukturelle problemer med lav produktivitet i Russland knyttes til problematiske migranter heller enn til problematiske institusjoner. Det å erstatte «dårlig» arbeidskraft med mer kvalifiserte arbeidere fremstilles som en løsning på denne utfordringen. Denne diskursen er fremtredende både i pro-myndighetavisene og i den opposisjonelle leiren. En slik diskurs forer etnisk nasjonalistiske holdninger, og dette er i sin tur dårlig kompatibelt med Russlands fleretniske befolkning.

I bokens femte kapittel tar Rustamjon Urinboyev for seg en transnasjonal og uformell (informal) praksis med å inngå avtaler po rukam - forseglet med håndtrykk. Forfatterens fokus er på uformelle praksiser i postsovjetiske samfunn, og han argumenterer for at slike praksiser er i ferd med å bli transnasionale. Arbeidsmigrantene lever på mange måter i to nasjonalstater, de deltar i praksiser og bidrar til økonomiske, sosiale og politiske prosesser i begge land. Urinboyevs velskrevne og spennende kapittel er basert på funnene fra et feltarbeid på en byggeplass i Moskva og i en landsby i Fergana i Uzbekistan. Byggebransjen i Moskva er preget av po rukamarbeidskontrakter som binder sammen en mengde aktører i store transnasjonale nettverk. Dette blir illustrert av Urinboyev med et plott og rolleregister et krimdrama 


\section{2}

verdig. Vi møter usbekiske arbeidsmigranter, usbekiske og russiske mellommenn, byggefirmaer, russiske politibetjenter, tsjetsjenske utpressere og arbeidsmigrantenes familier og lokalsamfunn i Usbekistan. Ved å bruke mangelen på utbetalt lønn som eksempel, lykkes forfatteren med å vise hvordan aktører i transnasjonale nettverk bruker maktmidlene de har til disposisjon til å påvirke hverandre. Urinboyev viser også hvordan konflikter kan løses ved hjelp av transnasjonale nettverk - lokalsamfunnet i Usbekistan kan bidra til at lønnen i Moskva blir utbetalt.

De to kapitlene illustrerer hvordan temaet "skyggeøkonomi» berøres i veldig ulik grad av bidragsyterne i boken. For Urinboyev er skyggeøkonomi et hovedtema, mens Lassilas bidrag kun tangerer temaet. Jeg er dermed usikker på hvorvidt boken har lyktes med å gjøre temaet skyggeøkonomi så sentral som det ble flagget i innledningskapittelet. For meg som leser er bokens viktige bidrag at den har samlet sammen flersidig og oppdatert forskning på migrasjonsfeltet i Russland. Jeg lærte noe nytt og det takker jeg redaktørene og bidragsyterne for. 